\title{
Septic shock, noradrenaline requirements and alpha- 2 agonists: Fishing in the right pond?
}

\author{
Auguste Dargent ${ }^{1}$, Luc Quintin ${ }^{2 *} \mathbb{D}$, Jean-Pierre Quenot ${ }^{1}$
}

Bellomo et al. [1] confirm the clinical [2-4] data showing a reduction in noradrenaline (NA) requirements in the setting of septic shock following administration of an alpha- 2 agonist, dexmedetomidine.

The intensivist is unaware that the retrospective analysis has thoroughly changed the design of the study from "sedation vs. outcome" to "sympathetic de-activation vs. circulation" (i.e., upregulation of alpha-1 receptors vs. NA requirements). Furthermore, the design is not optimal. SPICE III [5] compared early dexmedetomidine ("dex") versus usual sedation $(-2<$ RASS $<+1)$ [5]. Bellomo achieved RASS $\sim 4$, in both groups (results [1]): The dex group received also propofol (95\% of the patients), midazolam (43\%) and higher doses of opioids (Table S1 [1]). Thus, any effect of dex is drowned as a consequence of adding usual sedation to dex. Nevertheless, in the dex group, (a) the overall NA requirement ("NA equivalent") is lowered by $25 \%$, nonsignificantly, but of daily clinical relevance for the intensivist; (b) The NA requirement necessary to achieve a target pressure lowered, as a function of dose (i.e., compatible with a dosedependent sympathetic de-activation). NA requirements should be readdressed in the dexmedetomidine-only patients versus the usual sedation-only patients, throughout the whole SPICE III [5] database.

This comment refers to the article available online at https://doi.org/10.1186/ s13054-020-03115-x.

*Correspondence: lucquintinx@gmail.com

${ }^{2}$ Critical Care, Hôpital d'Instruction des Armées Desgenettes, Lyon, France

Full list of author information is available at the end of the article

\author{
Authors' response \\ Luca Cioccari, ${ }^{3,4}$ and Rinaldo Bellomo 4,5 \\ ${ }^{3}$ Department of Intensive Care Medicine, Inselspital, Bern University \\ Hospital, University of Bern, Bern, Switzerland. \\ ${ }^{4}$ Australian and New Zealand Intensive Care Research Centre, School \\ of Public Health and Preventive Medicine, Monash University, Prahran, VIC \\ 3004, Australia. \\ ${ }^{5}$ Centre for Integrated Critical Care, The University of Melbourne, \\ Melbourne, Australia.
}

We thank Dargent and colleagues for the comments about our study on the hemodynamic changes seen in patients with septic shock treated with dexmedetomidine as primary sedating agent versus usual care [1]. We agree that the retrospective nature of the study creates problems because the original study was a sedation trial with mortality as the outcome, while the retrospective investigation of the hemodynamic effects of dexmedetomidine was a post hoc physiological assessment in patients who were mostly deeply sedated at the time of investigation (median RASS of -3) and receiving propofol in most cases, fentanyl in the majority and midazolam in close to half of cases. In such a setting, the effect of dexmedetomidine is markedly attenuated by the impact of these drugs. Thus, we agree that it is all the more remarkable that, in the dexmedetomidine group, the overall norepinephrine (noradrenaline) requirements were lower and that the dose required to achieve target mean arterial pressure was also decreased. Finally, we agree that comparing patients on dexmedetomidine only versus patients receiving usual care would be ideal. Unfortunately, we were unable to identify such a cohort of patients. Nonetheless, within the limitations of the design and the population studied, we think that our findings are consistent with a substantial body of experimental data supporting the view that, in the septic, vasodilated state, 
dexmedetomidine (and central alpha-2 agonists) infusion does not exacerbate hypotension or increase vasopressor requirements but, in fact, appears to do the opposite [6-9].

\section{Abbreviations}

APACHE: Acute Physiology and Chronic Health Evaluation; NA: Noradrenaline; RASS: Richmond agitation-sedation scale.

\section{Acknowledgements}

Not applicable.

\section{Authors' contributions}

$A D, L Q$, and JPQ, contributed to the writing. All authors read and approved the final manuscript.

\section{Funding}

Not applicable.

\section{Availability of data and materials}

Not applicable.

Ethics approval and consent to participate

Not applicable.

\section{Consent for publication}

Not applicable.

\section{Competing interests}

$L Q$ received honoraria and unrestricted research grants from BoehringerIngelheim, France, UCB Pharma, Belgium, and Abbott International, II, USA [1986-1996], and holds US patent 8846606 B2, September 30, 2014 (method and drug composition for treating septic shock hypotension).

\section{Author details}

${ }^{1}$ CHU Dijon, Dijon, France. ${ }^{2}$ Critical Care, Hôpital d'Instruction des Armées Desgenettes, 120 Rue de la Pagère, 69500 Lyon, Bron, France. ${ }^{3}$ Department of Intensive Care Medicine, Inselspital, Bern University Hospital, University of Bern, Bern, Switzerland. ${ }^{4}$ Australian and New Zealand Intensive Care Research Centre, School of Public Health and Preventive Medicine, Monash University, Prahran, VIC 3004, Australia. ${ }^{5}$ Centre for Integrated Critical Care, The University of Melbourne, Melbourne, Australia. Received: 16 October 2020 Accepted: 5 November 2020
Received: 16 October 2020 Accepted: 5 November 2020

Published online: 09 February 2021

\section{References}

1. Cioccari L, Luethi N, Bailey M, Shehabi Y, Howe B, Messmer AS, et al. The effect of dexmedetomidine on vasopressor requirements in patients with septic shock: a subgroup analysis of the Sedation Practice in Intensive Care Evaluation [SPICE III] Trial. Crit Care. 2020;24:441. https://doi. org/10.1186/s13054-020-03115-X.

2. Pichot C, Mathern P, Khettab F, Ghignone M, Geloen A, Quintin L. Increased pressor response to noradrenaline during septic shock following clonidine? Anaesth Intensive Care. 2010;38:784-5.

3. Leroy S, Aladin L, Laplace C, Jalem S, Rosenthal J, Abrial A, et al. Introduction of a centrally anti-hypertensive, clonidine, reduces noradrenaline requirements in septic shock caused by necrotizing enterocolitis. Am J Emerg Med. 2017;35:e3-377.

4. Morelli A, Sanfilippo F, Arnemann P, Hessler M, Kampmeier TG, D'Egidio A, et al. The effect of propofol and dexmedetomidine sedation on norepinephrine requirements in septic shock patients: a crossover trial. Crit Care Med. 2018. https://doi.org/10.1097/CCM.0000000000003520.

5. Shehabi Y, Howe BD, Bellomo R, Arabi YM, Bailey M, Bass FE, et al. Early sedation with dexmedetomidine in critically III patients. N Engl J Med. 2019. https://doi.org/10.1056/NEJMoa1904710.

6. Lankadeva YR, Ma S, Iguchi N, et al. Dexmedetomidine reduces norepinephrine requirements and preserves renal oxygenation and function in ovine septic acute kidney injury. Kidney Int. 2019;96:1150-61.

7. Lankadeva YR, Booth LC, Kosaka J, et al. Clonidine restores pressor responsiveness to phenylephrine and angiotensin II in ovine sepsis. Crit Care Med. 2015:43:e221-9.

8. Morelli A, Sanfilippo F, Arnemann P, et al. The effect of propofol and dexmedetomidine sedation on norepinephrine requirements in septic shock patients: a cross over trial. Crit Care Med. 2019;47:e89-95.

9. Pichot C, Mathern P, Khettab F, et al. Increased pressor response to noradrenaline during septic shock following clonidine. Anaesth Intensive Care. 2010;38:784-5.

\section{Publisher's Note}

Springer Nature remains neutral with regard to jurisdictional claims in published maps and institutional affiliations.
Ready to submit your research? Choose BMC and benefit from:

- fast, convenient online submission

- thorough peer review by experienced researchers in your field

- rapid publication on acceptance

- support for research data, including large and complex data types

- gold Open Access which fosters wider collaboration and increased citations

- maximum visibility for your research: over 100M website views per year

At BMC, research is always in progress.

Learn more biomedcentral.com/submissions 